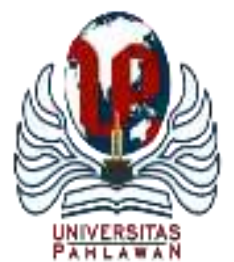

\title{
JURNALBASICEDU
}

Volume 6 Nomor 1 Tahun 2022 Halaman 1019 - 1027

Research \& Learning in Elementary Education

https://jbasic.org/index.php/basicedu

\section{Pelanggaran Prinsip Kesantunan Berbahasa Peserta Didik terhadap Guru Sekolah Dasar}

\author{
Kiftian Hady Prasetya ${ }^{1 凶}$, Hani Subakti $^{2}$, Ari Musdolifah ${ }^{3}$ \\ Universitas Balikpapan, Indonesia ${ }^{1,3}$, Universitas Widya Gama Mahakam, Indonesia ${ }^{2}$ \\ E-mail: kiftian@uniba-bpn.ac.id ${ }^{1}$, hanisubakti@uwgm.ac.id ${ }^{2}$, $\underline{\text { ari.musdolifah@uniba-bpn.ac.id }}^{3}$
}

\begin{abstract}
Abstrak
Fokus masalah dalam penelitian ini dilatarbelakangi oleh fenomena komunikasi oleh peserta didik terhadap guru yang kurang memperhatikan prinsip kesantunan berbahasa, secara khusus terjadi dalam proses pembelajaran di kelas dan di lingkungan sekolah sehingga perlu dilakukan analisis pelanggaran prinsip kesantunan berbahasa. Tujuan penelitian ini untuk mengetahui pelanggaran prinsip kesantunan berbahasa peserta didik terhadap guru di Kota Balikpapan. Penelitian ini menggunakan metode kualitatif deskriptif dengan pendekatan pragmatik. Data penelitian ini berupa teks tulis (transkrip percakapan) dari sumber data 73 peserta didik di Kota Balikpapan. Teknik pengumpulan data menggunakan tahapan observasi, teknik Simak Bebas Libat Cakap (SBLC), dan wawancara. Instrumen penelitian berupa gawai, alat tulis, buku catatan, dan tabel indikator prinsip kesantunan berbahasa. Hasil penelitian menemukan adanya 17 pelanggaran prinsip kesantunan berbahasa yang dilakukan oleh peserta didik terhadap guru di Kota Balikpapan. Temuan penelitian berupa: (1) maksim penerimaan, (2) maksim kemurahan, (3) maksim kerendahan hati, (4) maksim kesetujuan, dan (5) maksim kesimpatian dalam prinsip kesantunan berbahasa. Kesimpulan dalam penelitian ini menitikberatkan pada perhatian pelbagai lapisan masyarakat, lingkungan keluarga, dan lingkungan sekolah yang dapat dan mampu memberikan edukasi dalam komunikasi yang nantinya menjadi contoh nyata terhadap produksi komunikasi peserta didik dengan muatan prinsip kesantunan berbahasa.
\end{abstract}

Kata Kunci: Pragmatik, Prinsip Kesantunan Berbahasa.

\begin{abstract}
The focus of the problem in this research is motivated by the phenomenon of communication by students to teachers who do not pay attention to the principles of language politeness, specifically occurring in the learning process in the classroom and in the school environment so it is necessary to analyze violations of the principles of language politeness. The purpose of this study was to determine the violation of the principles of language politeness of students towards teachers in Balikpapan. This study uses a descriptive qualitative method with a pragmatic approach. The data of this research is in the form of written text (conversation transcripts) from the data source of 73 students in Balikpapan. The data collection technique used the observation stage, the technique of Simak Bebas Libat Cakap (SBLC), and interviews. Research instruments in the form of gadgets, stationery, notebooks, and table of politeness principle indicators. The results of the study found that there were 17 violations of the principle of language politeness committed by students against teachers in Balikpapan. The research findings are: (1) the maxim of acceptance, (2) the maxim of generosity, (3) the maxim of humility, (4) the maxim of agreement, and (5) the maxim of sympathy in the principle of politeness. The conclusion in this study focuses on the attention of various levels of society, the family environment, and the school environment who can and are able to provide education in communication which will later become a real example of the production of student communication with the content of the principle of politeness in language.
\end{abstract}

Keywords: Pragmatics, Principles of Language Simplicity

Copyright (c) 2022 Kiftian Hady Prasetya, Hani Subakti, Ari Musdolifah

$\triangle$ Corresponding author :

Email : kiftian@uniba-bpn.ac.id

DOI : https://doi.org/10.31004/basicedu.v6i1.2067

ISSN 2580-3735 (Media Cetak)

ISSN 2580-1147 (Media Online) 


\section{PENDAHULUAN}

Komunikasi terjalin dengan baik apabila penutur memiliki keterampilan berbahasa yang baik sehingga dapat dipahami oleh mitra tutur (Septika \& Prasetya, 2020, p. 2). Oleh sebab itu, keterampilan berbahasa sangat mempengaruhi keberhasilan komunikasi antar manusia. Komunikasi dapat berhasil apabila menggunakan strategi (Subakti, Salim, Prasetya, Septika, \& Oktaviani, 2021). Strategi dalam komunikasi digunakan penutur dan mitra tutur agar proses komunikasi dapat berjalan dengan baik. Kendala dalam berkomunikasi adalah perbedaan latar belakang budaya. Hal tersebut memicu proses komunikasi yang berlangsung tidak berjalan dengan semestinya karena kandungan makna yang digunakan penutur tidak tersampaikan dengan baik ke mitra tutur. Tidak adanya keberterimaan dan kesepahaman antara penutur dan mitra tutur dapat membuat komunikasi tidak berjalan dengan baik. Adanya perselisihan antara manusia satu dengan manusia yang lain, kelompok masyarakat dengan kelompok masyarakat yang lain dapat disebabkan oleh komunikasi yang tidak memperhatikan kesantunan. Demikian halnya, strategi bertutur yang baik dapat menghindari perselisihan antar manusia sehingga dapat meninggalkan kesan santun.

Tutur bahasa yang baik adalah tidak memiliki kesan angkuh dan memaksa. Tuturan akan terkesan santun apabila penutur memperhatikan bahasa yang akan disampaikan kepada mitra tutur. Yule (Anggraini, 2021, p. 43) menyatakan kesantunan adalah suatu prasyarat dalam berperilaku sosial yang berupa aturan dan ketentuan yang telah disepakati dan ditetapkan oleh suatu masyarakat tertentu. Kesantunan dalam berbahasa akan tercapai apabila mematuhi prinsip-prinsip kesantunan. Leech (Febriasari, 2018, p. 142) Prinsip-prinsip kesantunan berupa maksim kebijaksanaan (tact maxim), maksim kedermawanan (generosity maxim), maksim penerimaan (approbation maxim), maksim kerendahan hati (modesty maxim), maksim kesetujuan (agreement maxim), dan maksim kesimpatian (sympathy maxim).

Kesantunan berbahasa merupakan kegiatan pemilihan kata-kata yang baik dengan memperhatikan waktu dan mitra tutur (Chaer, 2010, p. 63). Kesantunan berbahasa merupakan etika dalam bersosialisasi di masyarakat, sebagai contohnya penggunaan kesantunan berbahasa di lingkungan sekolah.

Lingkungan sekolah memiliki peran dalam membentuk kesantunan berbahasa karena peserta didik banyak menghabiskan waktunya di sekolah. Guru berperan penting dalam memberikan contoh santun berbahasa kepada peserta didik di sekolah. Beragam strategi yang diberikan guru kepada peserta didik agar peserta didik dapat menggunakan bahasa yang santun. Komunikasi yang baik antara guru dan peserta didik dapat membuat situasi tetap terkendali. Permasalahan penelitian ini berkaitan dengan terdapatnya peserta didik yang masih kurang memperhatikan prinsip kesantunan dalam bertutur kepada guru. Ketidaksantunan tersebut muncul dalam proses pembelajaran di kelas, lingkungan sekolah, dan di luar sekolah.

Selama pandemi Covid-19, proses kegiatan belajar mengajar dilakukan secara online dengan menggunakan Zoom atau Google Meet. Guru dan peserta didik bertatap muka secara online dengan waktu yang terbatas. Hal tersebut yang membuat kurangnya kedekatan antara guru dan peserta didik dalam berkomunikasi. Akibatnya, ketidaksantunan bahasa peserta didik kepada guru banyak terjadi. Seperti halnya ketika peserta didik bertanya kepada guru tentang materi pelajaran melalui media sosial, yaitu Whatsapp. Banyak peserta didik yang menggunakan bahasa tidak baku dan tidak sopan kepada gurunya seperti yang terjadi pada peserta didik di Sekolah Dasar Kota Balikpapan.

Wawasan dan rencana pemecahan masalah dalam penelitian ini penting dilakukan untuk memahami pelanggaran prinsip kesantunan berbahasa peserta didik Sekolah Dasar di Kota Balikpapan. Selain itu, maraknya penggunaan bahasa milenial sekarang ini mengharuskan kesantunan berbahasa lebih ditingkatkan agar dapat mematuhi etika dalam berbahasa di masyarakat.

Rumusan tujuan penelitian dideskripsikan untuk mengetahui bagaimanakah pelanggaran prinsip kesantunan peserta didik Sekolah Dasar di Kota Balikpapan. Berdasarkan hasil observasi, masih banyak 
peserta didik yang melakukan pelanggaran prinsip kesantunan berbahasa kepada guru. Salah satu bentuk ketidaksantunan tersebut adalah berikut ini.

Peserta didik : "Pake tulis soal kah bu. Cape eh bu kalua tulis soal. Banyak banget bu. Udah lama ga nulis bu, nulis Panjang begitu cape."

Guru : "Iya nak...ga papa pelan-pelan saja...kan waktunya masih lama...nanti kalua ada yang kesulitan tanya ibu nak."

Peserta didik : "Jawabanya aja lah bu. Gila aja bagian A sampe C nulis soal bu. Belum tugas yang lain bu. Pengertiannya aja bu tolong."

Guru : :Gak bisa lah...nanti ibu bantu yang sulit."

Konteks dalam tuturan tersebut adalah tuturan terjadi antara guru dan peserta didik di luar dari proses pembelajaran. Tuturan ini dituturkan oleh peserta ketika meminta keringanan tugas kepada guru. Guru menugaskan untuk menulis semua soal, tetapi peserta didik meminta keringanan untuk menulis jawabannya saja. Tuturan tersebut merupakan bentuk pelanggaran prinsip kesantunan dalam maksim kesetujuan. Tuturan yang dituturkan oleh peserta didik kepada guru tersebut melanggar maksim kesetujuan karena tidak memaksimalkan kesetujuan dan meminimalkan ketidaksetujuan. Peserta didik mengajukan keringanan akan tugas yang diberikan oleh guru, tetapi guru menolaknya. Hal ini tidak sesuai dengan penerapan maksim kesetujuan yang menghendaki setiap peserta tutur untuk memaksimalkan kesetujuan dan meminimalkan ketidaksetujuan di antara mereka.

Kajian teoretik yang digunakan dalam penelitian ini berupa prinsip kesantunan oleh Leech untuk mengetahui pelanggaran prinsip kesantunan yang terdiri dari enam maksim, yaitu maksim kebijaksanaan, maksim penerimaan, maksim kemurahan, maksim kerendahan hati, maksim kesetujuan, dan maksim kesimpatian. Adapun harapan dan manfaat penelitian ini dapat menambah dan memperluas wawasan mengenai pelanggaran kesantunan berbahasa. Penelitian ini memiliki manfaat teoretis yang dapat digunakan sebagai tambahan pengetahuan yang baru serta menjadi rujukan dalam berkomunikasi menggunakan kesantunan dalam berbahasa. Selanjutnya, penelitian ini bermanfaat untuk menjadi acuan, referensi, dan dokumentasi pada pelanggaran kesantunan berbahasa di masa yang akan datang. Selain itu, penelitian ini dapat memberikan sumbangan kepada masyarakat pengguna bahasa yang berupa wawasan dalam penggunaan bahasa agar menjadi gambaran mengenai pelanggaran kesantunan berbahasa di masyarakat dalam keadaan nyata maupun di media sosial.

Penelitian tentang pelanggaran prinsip kesantunan berbahasa pernah dilakukan oleh (Veronica, 2021), (Elvira, 2021), (Faridah, 2021), (Akbar, 2021), (Nisa, 2021), (Sari, 2021) dengan fokus penelitian kesantunan berbahasa. Berdasarkan hasil dan pembahasan penelitian-penelitian tersebut, ditemukan bentuk-bentuk pematuhan dan pelanggaran kesantunan yang mencakup maksim kebijaksanaan, maksim penghargaan, maksim permufakatan, dan maksim kesimpatian.

Kebaruan penelitian ini lebih berfokus pada pelanggaran prinsip kesantunan berbahasa dalam pembelajaran daring melalui grup whatsapp. Sedangkan penelitian terdahulu lebih berfokus pada pembelajaran luring di kelas secara langsung. Kesenjangan dalam penelitian ini dihadapkan pada kesesuaian teori prinsip kesantunan berbahasa yang seharusnya diterapkan oleh peserta didik terhadap guru dalam proses pembelajaran. Pentingnya penelitian ini dilakukan untuk mendeskripsikan pelanggaran-pelanggaran dalam prinsip kesantunan berbahasa yang terjadi dalam proses pembelajaran daring sehingga menjadi acuan ukur terhadap evaluasi penerapan kesantunan berbahasa dalam proses pembelajaran. 
1022 Pelanggaran Prinsip Kesantunan Berbahasa Peserta Didik terhadap Guru Sekolah Dasar - Kiftian Hady Prasetya, Hani Subakti, Ari Musdolifah

DOI: https://doi.org/10.31004/basicedu.v6i1.2067

\section{METODE PENELITIAN}

Penelitian ini merupakan penelitian kualitatif (Sugiyono, 2016, p. 243), (Moleong, 2017, p. 6), (Mahsun, 2019, p. 356), (Mamik, 2015, p. 118). Penelitian kualitatif sebagai prosedur penelitian yang menghasilkan data deskriptif berupa kata-kata tertulis atau lisan dari orang-orang dan perilaku yang dapat diamati. Metode yang digunakan dalam tulisan ini adalah metode deskriptif. Metode deskriptif untuk memaparkan data dan menguraikannya sesuai dengan sifat alamiah data yang diperoleh (cara menuturkan, mengklasifikasikan, dan menganalisisnya).

Metode penelitian kualitatif dalam penelitian ini bertujuan untuk mendeskripsikan pelanggaran prinsip kesantunan berbahasa peserta didik terhadap guru di Sekolah Dasar Kota Balikpapan. Prinsip-prinsip kesantunan berupa (1) maksim kebijaksanaan (tact maxim), (2) maksim kedermawanan (generosity maxim), (3) maksim penerimaan (approbation maxim), (4) maksim kerendahan hati (modesty maxim), (5) maksim kesetujuan (agreement maxim), dan (6) maksim kesimpatian (sympathy maxim) serta dianalisis menggunakan perspektif pendekatan pragmatik (Yule, 2014, p. 12), (Djatmika, 2016, p. 6), (Pranowo, 2014, p. 30), (Djajasudarma, 2010, p. 65).

Pendekatan pragmatik digunakan dengan landasan untuk mengetahui pelanggaran prinsip kesantunan berbahasa peserta didik terhadap guru di Sekolah Dasar Kota Balikpapan. Pendekatan ini dinilai tepat untuk mengkaji tentang pelanggaran kesantunan berbahasa dalam kaitannya dengan penggunaan bahasa di lingkungan sekolah dan masyarakat. Berdasarkan hal tersebut, jenis penelitian ini merupakan penelitian deskriptif kualitatif dengan pendekatan pragmatik yang bertujuan untuk mendeskripsikan secara sistematis, faktual dan akurat dari fenomena atau objek tertentu, yaitu pelanggaran prinsip kesantunan berbahasa peserta didik terhadap guru di Sekolah Dasar Kota Balikpapan.

Dalam penelitian ini, sumber data yaitu 34 peserta didik dari 73 peserta didik kelas VI SDN 014 dan SDN 012 Kota Balikpapan. Peserta didik yang berjumlah 17 tersebut dipilih menggunakan purposive sampling. Pertimbangan yang dilakukan adalah dengan mencari kriteria sesuai dengan fenomena yang diteliti. Kriteria tersebut adalah kata-kata peserta didik dalam sosial media Whatsapp yang mengandung pelanggaran prinsip kesantunan berbahasa. Data penelitian ini berupa teks tertulis percakapan pada bulan Oktober 2021 hingga bulan November 2021 di kelas VI SDN 014 dan SDN 012 Kota Balikpapan.

Teknik pengumpulan data yang digunakan pada penelitian ini antara lain adalah teknik simak dan catat. Tehnik simak dan catat dalam penelitian ini dilakukan dengan membaca secara berulang-ulang teks tertulis melalui sosial media Whatsapp peserta didik kelas VI SDN 014 dan SDN 012 Kota Balikpapan dengan guru mata pelajaran Bahasa Indonesia. Selanjunya, data dikelompokkan sesuai dengan pelanggaran prinsip kesantunan berbahasa

Selanjutnya, wawancara digunakan sebagai teknik pengumpulan data karena peneliti ingin melakukan studi pendahuluan untuk menemukan permasalahan yang akan diteliti dan juga peneliti ingin mengatahui halhal dari responden yang lebih mendalam. Wawancara yang dilakukan peneliti dalam hal ini adalah wawancara tidak terstruktur.

Instrumen penelitian berupa gawai, alat tulis, buku catatan, dan tabel indikator pelanggaran prinsip kesantunan berbahasa. Peneliti menggunakan teknik analisis data model dari Miles and Huberman (Sugiyono 2016) mengemukakan bahwa aktivitas dalam analisis data kualitatif dilakukan secara terus menerus sampai tuntas, sehingga datanya sudah jenuh. Aktivitas dalam analisis data yaitu reduksi data (data reduction), penyajian data (data display), dan penarikan simpulan (verification).

\section{HASIL DAN PEMBAHASAN}

Hasil penelitian ditemukan bahwa pelanggaran prinsip kesantunan teori Leech menggunakan 6 maksim yang dilakukan terhadap tuturan peserta didik kelas VI SDN 014 dan SDN 012 Kota Balikpapan, yaitu ditemukan 3 tuturan yang mengandung pelanggaran maksim penerimaan, 4 tuturan mengandung pelanggaran 
1023 Pelanggaran Prinsip Kesantunan Berbahasa Peserta Didik terhadap Guru Sekolah Dasar - Kiftian Hady Prasetya, Hani Subakti, Ari Musdolifah

DOI: https://doi.org/10.31004/basicedu.v6i1.2067

maksim kemurahan, 3 tuturan mengandung pelanggaran maksim kerendahan hati, 6 tuturan mengandung pelanggaran maksim kesetujuan, 1 tuturan mengandung pelanggaran maksim kesimpatian.

\section{Tabel Data Hasil Penelitian Pelanggaran Prinsip Kesantunan Peserta Didik terhadap Guru Kelas VI} SDN 014 dan SDN 012 Kota Balikpapan

\begin{tabular}{ccc}
\hline No & Pelanggaran Maksim & Jumlah Tuturan \\
\hline 1 & Maksim Kebijaksanaan & 0 \\
\hline 2 & Maksim Penerimaan & 3 \\
\hline 3 & Maksim Kemurahan & 4 \\
\hline 4 & Maksim Kerendahan Hati & 3 \\
\hline 5 & Maksim Kesetujuan & 6 \\
\hline 6 & Maksim Kesimpatian & 1 \\
\hline & Jumlah & $\mathbf{1 7}$ \\
\hline
\end{tabular}

Berdasarkan data yang telah didapatkan dengan melakukan pengelompokan pelanggaran prinsip kesantunan berdasarkan jenis maksim yang telah ditemukan, yaitu maksim kebijaksanaan, maksim penerimaan, maksim kemurahan, maksim kerendahan hati, maksim kesetujuan, maksim kesimpatian, maka dapat dijabarkan sebagai berikut ini.

\section{Pelanggaran Maksim Kesetujuan}

Maksim kesetujuan mengharuskan penutur dan lawan tutur saling menyetujui dan menghargai setiap tuturan yang dituturkan. Maksim kesetujuan menghendaki agar setiap penutur dan lawan tutur memaksimalkan kesetujuan di antara mereka; dan meminimalkan ketidak setujuan di antara mereka (Chaer, 2010, p. 58-59). Pelanggaran maksim kesetujuan dapat dilihat pada tuturan berikut ini.

Kode Data : P.Mks.Ksj /1

Guru : :Tugasnya dikumpul besok!"

Peserta didik : "Hemm banyak tugas eh Bu belum magang mknya saya kerjakan tugas malam"

Guru : : "Gpp pelan-pelan saja...ada yg kesulitan kah? Tanya aja ya nanti ibu bantu”

Peserta didik : "Ndaa kok Bu mata aja yang ngantuk"

Konteks dalam tuturan tersebut terjadi antara guru dan peserta didik di luar dari proses pembelajaran. Tuturan ini dituturkan oleh peserta didik yang bernama Rudi karena Rudi belum mengumpulkan tugas yang diberikan oleh guru. Guru bermaksud untuk mengingatkan Rudi agar segera mengumpulkan tugasnya.

Data P.Mks.Ksj/1 merupakan bentuk pelanggaran prinsip kesantunan dalam maksim kesetujuan. Pada tuturan tersebut terdapat pelanggaran maksim kesetujuan yang dituturkan oleh peserta didik bernama Rudi, yaitu pada tuturan "Hemm banyak tugas eh Bu belum magang mknya saya kerjakan tugas malam". Tuturan yang dituturkan oleh Rudi kepada guru tersebut melanggar maksim kesetujuan karena tidak memaksimalkan kesetujuan dan meminimalkan ketidaksetujuan. Peserta didik yang bernama Rudi mengajukan penolakan atau ketidak setujuan terhadap tuturan guru untuk segera mengumpulkan tugas karena Rudi ingin mengerjakan tugas yang lainnya. Hal ini tidak sesuai dengan penerapan maksim kesetujuan yang menghendaki setiap peserta tutur untuk memaksimalkan kesetujuan di antara mereka dan meminimalkan ketidak setujuan di antara mereka.

\section{Pelanggaran Maksim Kerendahan Hati}

Maksim kerendahan hati mengharuskan penutur untuk berkomunikasi dengan baik dengan mengurangi pujian pada dirinya sehingga lawan tutur dapat menilai penutur tersebut sopan dan rendah hati. Maksim kerendahan hati menuntut setiap peserta tuturan untuk memaksimalkan ketidakhormatan pada diri sendiri, dan 
1024 Pelanggaran Prinsip Kesantunan Berbahasa Peserta Didik terhadap Guru Sekolah Dasar - Kiftian Hady Prasetya, Hani Subakti, Ari Musdolifah

DOI: https://doi.org/10.31004/basicedu.v6i1.2067

meminimalkan rasa hormat pada diri sendiri (Chaer, 2010, p. 58-59). Pelanggaran maksim kerendahan hati dapat dilihat pada tuturan berikut ini.

Kode data: P.Mks.KH/1

Peserta didik : "Asssallammualaikum bu. Saya Mohammad ingin menanyakan perihal nilai tugas LKS yang ibu berikan pada minggu kemarin, kemarin saya sudah memberikan foto hasil tugas saya ke ibu. Tapi ibu belum juga memberikan nilai kepada saya.? 'Padahal saya anak yang rajin mengerjakan tugas ibu."

Guru : : "Waalaikumsalam nak... iya Mohammad kelas berapa dan jurusan apa nanti supaya ibu cek."

Konteks dalam tuturan tersebut adalah tuturan terjadi antara guru dan peserta didik di luar dari proses pembelajaran. Tuturan ini dituturkan oleh peserta didik yang bernama Mohammad ketika bertanya tentang hasil nilai tugas LKS kepada guru. Mohammad memberikan pernyataan kepada guru bahwa ia anak yang rajin mengerjakan tugas. Kemudian, guru segera menelusuri nilai dari Mohammad.

Data P.Mks.KH/1 merupakan bentuk pelanggaran prinsip kesantunan dalam maksim kerendahan hati. Pada tuturan tersebut terdapat pelanggaran maksim kerendahan hati yang dituturkan oleh peserta didik bernama Mohammad yaitu pada tuturan 'Padahal saya anak yang rajin mengerjakan tugas ibu." Tuturan yang dituturkan oleh Mohammad kepada guru tersebut melanggar maksim kerendahan hati karena tidak memaksimalkan ketidakhormatan pada diri sendiri dan meminimalkan rasa hormat pada diri sendiri. Peserta didik yang bernama Mohammad bertanya kepada guru tentang nilai tugas dari LKS yang belum ia terima dengan membanggakan dirinya sendiri. Hal ini tidak sesuai dengan penerapan maksim kerendahan hati yang menuntut setiap peserta tuturan untuk memaksimalkan ketidakhormatan pada diri sendiri dan meminimalkan rasa hormat pada diri sendiri

\section{Pelanggaran Maksim Penerimaan}

Maksim penerimaan menjelaskan bahwa orang akan dianggap santun apabila memaksimalkan kerugian bagi diri sendiri dan memaksimalkan keuntungan diri. Maksim penerimaan menghendaki setiap peserta pertuturan untuk memaksimalkan kerugian bagi diri sendiri dan meminimalkan keuntungan diri sendiri (Chaer, 2010, p. 57. Pelanggaran maksim penerimaan dapat dilihat pada data berikut.

Kode data: P.Mks.Pn/1

Peserta didik : "Saya mau tanya bu gimana caranya buat makalah."

Guru : "Silakan dibaca di materi yang ibu kirim nak...di situ sudah dijelaskan."

Peserta didik : "Udah bu tapi kurang jelas tolong dijelasin lagi bu."

Konteks dalam tuturan tersebut adalah tuturan terjadi antara guru dan peserta didik di luar dari proses pembelajaran. Tuturan ini dituturkan oleh peserta didik yang bernama Geri ketika bertanya tentang materi kepada guru. Guru memberikan pernyatan bahwa Geri bisa membaca materi dari yang sudah diberikan.

Data P.Mks.Pn/1 merupakan bentuk pelanggaran prinsip kesantunan dalam maksim penerimaan. Pada tuturan tersebut terdapat pelanggaran maksim penerimaan yang dituturkan oleh peserta didik bernama Geri yaitu pada tuturan "Udah bu tapi kurang jelas tolong dijelasin lagi bu." Tuturan yang dituturkan oleh Geri kepada guru tersebut melanggar maksim penerimaan karena tidak memaksimalkan kerugian bagi dirinya sendiri. Peserta didik yang bernama Geri bertanya kepada guru tentang materi yang belum ia pahami dan guru menyatakan bahwa Geri bisa membaca dari materi yang sudah diberikan. Geri menyatakan bahwa ia sudah membacanya dan masih belum paham. Oleh karena itu, ia meminta kepada guru untuk menjelaskan lagi. Hal 
1025 Pelanggaran Prinsip Kesantunan Berbahasa Peserta Didik terhadap Guru Sekolah Dasar - Kiftian Hady Prasetya, Hani Subakti, Ari Musdolifah

DOI: https://doi.org/10.31004/basicedu.v6i1.2067

ini tidak sesuai dengan penerapan maksim penerimaan yang menuntut setiap peserta tuturan untuk memaksimalkan kerugian bagi diri sendiri dan meminimalkan keuntungan diri sendiri.

\section{Pelanggaran Maksim Kemurahan}

Maksim kemurahan menjelaskan bahwa orang akan dianggap santun apabila dalam bertutur selalu berusaha memberikan kepada pihak lain dan tidak saling mencaci dan mengejek satu sama lain. Maksim kemurahan menuntut setiap peserta tuturan untuk memaksimalkan rasa hormat kepada orang lain dan meminimalkan rasa tidak hormat kepada orang lain (Chaer, 2010, p. 57-58). Pelanggaran maksim kemurahan dapat dilihat pada data berikut ini:

Kode data: P.Mks.Kmn/1

Peserta didik : "Assallammualaikum bu. Bu saya pengen lihat nilaiku yang kosong apa aja? Gesit bu..."

Guru : "Iya nak sebentar ibu masih nyari datanya le..."

Konteks dalam tuturan tersebut adalah tuturan terjadi antara guru dan peserta didik di luar dari proses pembelajaran. Tuturan ini dituturkan oleh peserta didik yang bernama Taha ketika menanyakan nilai kepada guru. Taha menanyakan nilainya kepada guru disertai dengan suruhan. Guru menjawab kalau nilainya Taha sedang dicarikan.

Data P.Mks.Kmn/1 merupakan bentuk pelanggaran prinsip kesantunan dalam maksim kemurahan Pada tuturan tersebut terdapat pelanggaran maksim kemurahan yang dituturkan oleh peserta didik bernama Taha yaitu pada tuturan "Gesit bu" Tuturan yang dituturkan oleh Taha kepada guru tersebut melanggar maksim kemurahan karena tidak memaksimalkan rasa hormat kepada orang lain dan meminimalkan rasa tidak hormat kepada orang lain. Peserta didik yang bernama Taha menanyakan nilainya kepada guru dengan memberikan suruhan kepada guru untuk melakukannya dengan cepat. Hal yang dituturkan Taha tersebut tidak sopan dan tidak memiliki rasa hormat kepada orang tua khususnya guru. Hal ini tidak sesuai dengan penerapan maksim kemurahan yaitu memaksimalkan rasa hormat kepada orang lain dan meminimalkan rasa tidak hormat kepada orang lain.

\section{Pelanggaran Maksim Kesimpatian}

Maksim kesimpatian mengharuskan penutur untuk dapat memaksimalkan rasa simpati dan meminimalkan rasa antipati kepada lawan tutur. Pelanggaran maksim kesimpatian dapat dilihat pada data berikut.

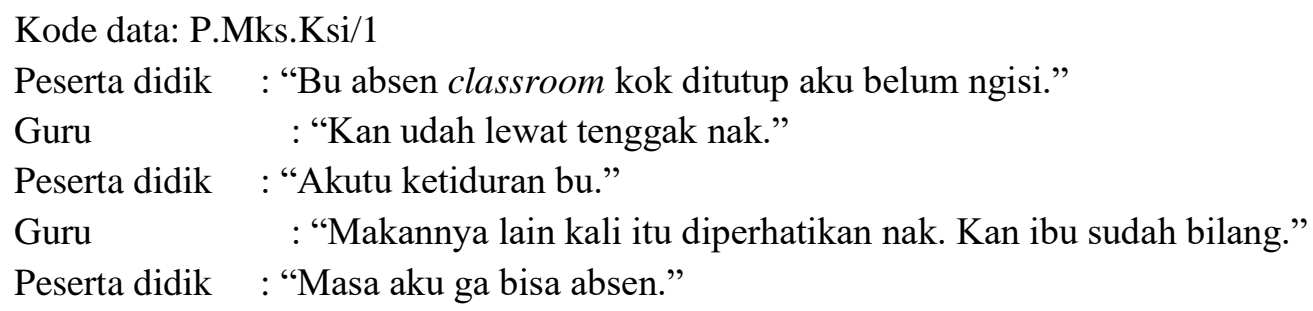

Konteks dalam tuturan tersebut adalah tuturan terjadi antara guru dan peserta didik di luar dari proses pembelajaran. Tuturan ini dituturkan oleh peserta didik yang bernama Tiskha karena terlambat untuk mengisi daftar hadir pembelajaran di Google Classroom. Tiskha mengatakan keberatannya atas hal tersebut kepada guru. 
1026 Pelanggaran Prinsip Kesantunan Berbahasa Peserta Didik terhadap Guru Sekolah Dasar - Kiftian Hady Prasetya, Hani Subakti, Ari Musdolifah

DOI: https://doi.org/10.31004/basicedu.v6i1.2067

Data P.Mks.Ksi/1 merupakan bentuk pelanggaran prinsip kesantunan dalam maksim kesimpatian. Pada tuturan tersebut terdapat pelanggaran maksim kesimpatian yang dituturkan oleh peserta didik bernama Tiskha yaitu pada tuturan "Masa aku ga bisa absen." Tuturan yang dituturkan oleh Tiskha kepada guru tersebut melanggar maksim kesimpatian karena tidak memaksimalkan rasa simpati dan meminimalkan rasa antipasti. Peserta didik yang bernama Tiskha mengatakan kepada guru bahwa ia ingin mengisi daftar hadir di Google Classroom, tetapi guru mengatakan bahwa ia tidak bisa mengisi daftar hadir karena sudah terlambat. Tuturan Tiskha tersebut menandakan tidak adanya rasa simpati kepada guru karena ia tetap mempertahankan pernyataannya. Hal ini tidak sesuai dengan penerapan maksim kemurahan yaitu mengharuskan penutur untuk dapat memaksimalkan rasa simpati dan meminimalkan rasa antipati kepada lawan tutur.

Temuan penelitian menunjukkan bahwa terdapat beberapa pelanggaran prinsip kesantunan berbahasa yang dilakukan oleh peserta didik terhadap guru dalam proses pembelajaran. Pelanggaran prinsip kesantunan berbahasa di kelas memiliki keterkaitan dengan perkembangan-perkembangan yang terjadi dengan peserta didik dan guru pada proses pembelajaran. Perkembangan proses pembelajaran yang menyebabkan pelanggaran prinsip kesantunan berbahasa pada penilitian ini berkaitan erat dengan perilaku peserta didik maupun perilaku guru yang terbentuk atas adanya serapan dan masukan dari pola interaksi-interaksi yang terjadi di lingkungan guru dan peserta didik. Penggunaan tuturan pada interaksi di lingkungan tempat tinggal yang berbeda, secara perlahan akan memengaruhi pelanggaran prinsip kesantunan berbahasa di kelas selama proses pembelajaran.

\section{KESIMPULAN}

Berdasarkan pada hasil analisis data penelitian, disimpulkan bahwa pelanggaran prinsip kesantunan berbahasa peserta didik kelas X terhadap guru di SMK Setia Budi Balikpapan dapat diperoleh kesimpulan terkumpul sebanyak 17 tuturan yang mengandung pelanggaran prinsip kesantunan berbahasa menurut Leech. Diantaranya yaitu a) maksim kesimpatian 1 tuturan, b) maksim kesetujuan 6 tuturan, c) maksim kemurahan 4 tuturan, d) maksim kerendahan hati 3 tuturan, e) maksim kebijaksanaan 0 tuturan, f) maksim penerimaan 3 tuturan. Pelanggaran prinsip kesantunan berbahasa dilakukan pada maksim kesetujuan karena peserta didik banyak mengeluh terhadap tugas-tugas yang diberikan oleh guru.

\section{DAFTAR PUSTAKA}

Akbar, M. H. (2021). Kesantunan Dan Ketidaksantunan Berbahasa Masyarakat Sunda Dalam Dialog Percakapan Pada Acara Kunjungan Keluarga Di Beberapa Tempat Di Jawa Barat. Jurnal Al-Tsaqafa, 95-120.

Anggraini, N. R. (2021). Kesantunan Berbahasa Indonesia Dalam Pembelajaran Di Kelas X MAN 1 Model Kota Bengkulu. Junal Llmiah Korpus, 42-54.

Chaer, A. (2010). Kesantunan Berbahasa. Jakarta: PT. Rineka Cipta.

Djajasudarma. (2010). Wacana. Bandung: PT. Refika Aditama.

Djatmika. (2016). Mengenal Pragmatik. Yogyakarta: Pustaka Pelajar.

Elvira, S. (2021). Pelanggaran Prinsip Kesantunan Berbahasa Dalam Film Tullah. Jurnal Pendidikan Dan Pembelajaran Khatulistiwa, 1-11.

Faridah, S. (2021). Pelanggaran Prinsip Kesantunan Dalam Sastra Lisan Madihin. Jurnal Kredo, 36-52.

Febriasari, D. \&. (2018). Kesantunan Berbahasa Dalam Proses Pembelajaran Di Sekolah Dasar. Jurnal Kredo, 140-156.

Mahsun. (2019). Metode Penelitian Bahasa. Depok: Raja Grafindo Persada. 
1027 Pelanggaran Prinsip Kesantunan Berbahasa Peserta Didik terhadap Guru Sekolah Dasar - Kiftian Hady Prasetya, Hani Subakti, Ari Musdolifah

DOI: https://doi.org/10.31004/basicedu.v6i1.2067

Mamik. (2015). Metodologi Kualitatif. Sidoarjo: Zifatama Publisher.

Moleong, L. (2017). Metodologi Penelitian Kualitatif. Bandung: PT. Remaja Rosdakarya Offset.

Nisa, F. (2021). Pelanggaran Prinsip Kesantunan Dalam Wacana Tutur Basuki Tjahaja Purnama (Ahok). Jurnal Stilistika, 19-30.

Pranowo. (2014). Teori Belajar Bahasa. Yogyakarta: Pustaka Pelajar.

Sari, E. S. (2021). Pelanggaran Prinsip Kesantunan Berbahasa Dalam Acara Dua Arah Kompas TV. Jurnal Sapala, 1-10.

Septika, H. D., \& Prasetya, K. H. (2020). Local Wisdom Folklore For Literary Learning In Elementary School. Pendas: Jurnal Ilmiah Pendidikan Dasar, 13-24.

Subakti, H., Salim, N. A., Prasetya, K. H., Septika, H. D., \& Oktaviani, S. (2021). Does Learning In Mother Tongue Matter? Analysis Of The Use Of Kutai Language In Elementary Schools Learning. Ilkogretim Online, 421-426.

Subakti, H., \& Prasetya, K. H. (2020). Pengaruh Pemberian Reward And Punishment Terhadap Motivasi Belajar Bahasa Indonesia Siswa Kelas Tinggi Di Sekolah Dasar. Jurnal Basataka, 106-117.

Sugiyono. (2016). Metode Penelitian Kuantitatif, Kualitatif, Dan R\&D. Bandung: CV. ALFABETA.

Veronica, R. N. (2021). Analisis Kesantunan Berbahasa Indonesia Siswa Dan Guru SMP Negeri 03 Kota Bengkulu. Jurnal Ilmiah Korpus, 35-47.

Yule. (2014). Pragmatik. Yogyakarta: Pustaka Pelajar. 